\title{
Does Asymmetry of Information Drive Banks' Capital Structure? Empirical Evidence from Jordan
}

\author{
Ayman Mansour Alkhazaleh ${ }^{1} \&$ Mahmoud Khalid Almsafir $^{1}$ \\ ${ }^{1}$ Graduate Business School, College of Graduate Studies, Universiti Tenaga Nasional (Uniten), Malaysia \\ Correspondence: Ayman Mansour Alkhazaleh, Graduate Business School, College of Graduate Studies, \\ Universiti Tenaga Nasional (Uniten), Jalan IKRAM-UNITEN, 43300 Kajang, Selangor, Malaysia. E-mail: \\ ayman.alkhazaleh@gmail.com
}

Received: December 16, 2014

Accepted: January 9, 2015

Online Published: February 25, 2015

doi:10.5539/ijef.v7n3p86

URL: http://dx.doi.org/10.5539/ijef.v7n3p86

\begin{abstract}
In search of the applicability of the capital structure theory (Pecking Order Theory) this study seek to penetrate into the most important factors on a bank's capital structure using panel data derived from 14 Jordanian banks quoted on the Amman Stock Exchange of 2013 over the time span of 15 years (1999-2013). The feasible generalised least squareis used in this study as the analysis model and Size serves to be a moderator variable. The results have demonstrated that out of three variables, tow (dividends and tangibility) are significantly linked with leverage, whereas the remaining is insignificantly associated with leverage. It is indicated that dividends and tangibility appear to function as the determinants of capital structure. The dividend has a negative effect on capital structure. It implies that although banks favor to payout dividends to shareholders, less debt capital is used. Tangibility affects capital structure positively. The greater tangibility necessitates the use of more debt in capital structure to fund all the activities. Bank size does not moderate the effects of growth, dividends and tangibility on the capital structure. It also appears that this study shows evidence in Jordan banks relatively and somewhat complies with the pecking order theory. The findings are of useful for both investors and managers.
\end{abstract}

Keywords: determinants, capital structure, Pecking Order Theory, Jordan

\section{Introduction}

Fundamentally, the banking sector is regarded as the nucleus of any economy, and at the same time an essential part of the financial services industry. Its functionality in the economic growth and its proven enhancement of the financial markets are irrefutable. Broadly speaking, the accomplishments of banks are governed by the effectiveness of their investment framework and the efficiency of the capital structure.

In spite of the fact that equity financing is more expensive, as opposed to employing debt, both elements have to be kept realistically stable. Therefore, the capital structure has been seen as one of the financial factors, which can potentially connote banks' health conditions (Marc, 2010).

The obvious mutual understanding on the topic lies in the fact that no individual theory of capital structure has the capability to explain the observed capital structure decision of banks.Up until today, the Pecking Order Theory still thrives as a vital part of corporate finance. It has been deemed as one of the most important notions. Modigliani and Miller (1958) have established the principle of financing and added that the capital structure decision is not backed by adequate influence on bank value; how it is funded gets inconsequential, based on ideal market conditions and without bankruptcy, tax, and other related costs. Following their introductory research, many contemporary concepts - Trade-off Theory and Pecking Order Theory as two examples- have been suggested. However, the latest works have pointed out that there is a turning of attention towards Pecking Order Theory compared to the Trade off Theory (Simiyu \& Huo, 2013).

The assumption of the Pecking Order Theory is that there is no target capital structure involved. Notwithstanding, this theory indicates that, banks' covering of financing deficits does not depend on the existing debt levels, and that the banks always choose internal funds as against external funds and debt against equity.

It has been suggested by Myers and Majluf (1984) that the decision of the capital structure is motivated by the scale of information asymmetry that exists between the bank's management (insiders) and the external shareholders (outsiders). When the information discrepancy proves to be more critical, the more the external 
shareholders will have to confront more risks, and in effect they will demand more discount on the price of the issued securities.

It is suggested by this theory that, managers carry more information about the investment decisions and returns related to these investments compared to the stakeholders. Consequently, investors would prefer to purchase stocks on discount, in case if there is a discrepancy of information between managers and investors. Thus, to prevail over this problem, bank has to determine its structure in financing its assets.

A panel data from 14 banks over the period (1999-2013) is used to identify the probable information that can be used to support the applicability of the Pecking Order Theory in Jordan. It can help the decision makers in Jordanian financial authorities to properly examine the current situation and to initiate a better revision of measurements, standards and policies to the point that the banking sector can safely operate.

\section{Literature Review}

Pecking Order Theory is generally perceived as an antithesis of the Trade-off Theory. A number of studies have discussed the pecking order model as well, and concluded that, this model has embedded much higher informative power than other models (Karadeniz et al., 2009; Ahmad et al., 2009).

Furthermore, Myers (1984) reports that banks determine their financial structure, depending on the law of least effort. His further contention is that, if a bank issues new share, then the investors presumes that, the bank is overvalued and managers will reap the benefit from this overvaluation.

Findings of Gropp and Heider (2007) have not recognised a considerable impact of deposit insurance coverage on the capital structure of banks. It is consistent with the prediction of the Pecking Order Theory.

De Jong, Verbeek, and Verwijmeren (2008) have examined 6000 US banks from 1985 to 2005, and results have come up with some proof to support the Pecking Order Theory. Additionally, based on global sample using more than 6,000 banks from 1995 to 2005 Bessler, Drobetz, and Gruninger (2010) have made their validation on the Pecking Order Theory.

Moreover, there was also a confirmation from Leary and Roberts (2010) that, many banks support the assumption of the Pecking Order Theory, and preferably tend to debt financing rather than the equity financing.

De Jong, Verbeek, and Verwijmeren (2011) performed an assessment on the Pecking Order Theory as opposed to the static Trade off Theory. Their concentration was on a significant difference in prediction: the Pecking Order issues debt till the debt potential has been achieved, while the static Trade off Theory states that, a bank raises leverage till it achieves its target debt ratio. For example, the Pecking Order Theory was deemed a better descriptor for issuing bank decisions, as compared to the static Trade off Theory in U.S. banks during 1985-2005. Conversely, they have focused on repurchase decisions, and having learned that, the static Trade off Theory is a more robust predictor of the capital structure decisions of banks.

Atiyet (2012) aimed to revisit the capital structure theory and compares the explanatory power of the Static Trade-off theory and Pecking Order Theory using panel data of French firms belonging to SBF 250 index during the period 1999 to 2005 . The outcomes show that both empirical models explaining the capital structure favors the Pecking Order Theory.

Dang (2013) examined Pecking Order Theory and Trade off Theory employing an error correction model of leverage for firms in the UK, France and Germany. The work found that UK, French and German firms quickly adjust towards target leverage in both models. The results further indicate that the trade-off theory explains capital structure decisions better than the Pecking Order Theory.

Jindrichovska et al. (2013) examined two of the most relevant theories that explain financial policy in small and medium enterprises (SMEs): Trade-off Theory and Pecking Order Theory. A panel data is used to test the empirical hypotheses over the sample of 260 Czech SMEs over the years 2004-2011. The findings state that both approaches contribute to explain capital structure in Czech SMEs and identify major forces that lie behind their financial obligation.

Oolderink (2013) analyzed whether the static Trade-off Theory or the Pecking-Order Theory prevails in capital structure decisions made by Dutch listed firms. This study finds that the Pecking-Order Theory in capital structure decisions prevail while there is moderate support for the static Trade-off. Similarly, Roerink (2014) aimed at testing static Trade off and Pecking Order Theory predictions on capital structure in a Dutch context. Moderate support has been found for the both theories.

Serrasqueiro (2014) verified if financial theories can explain the capital structure of European and U.S. listed firms over the period 1996 and 2007. The results derived show the existence of a negative association between 
the explantory variables (liquidity and profitability) and debt complys with the Pecking Order Theory.

A lot of studies have been carried out in developing countries in support of the Pecking Order Theory. To this end, Abu Jalal (2007) has analyzed 17000 non-financial firms across 41 nations, and he discovers negative selection costs and information imbalance that lead to debt issues. However, concurrently these two elements appear to have failed to play a crucial role in developed countries as opposed to their developing counterparts.

Caglayan and Sak (2010) next, studied the firm-specific factors on decision of capital structure of banks in Turkey from 1992 to 2007. The findings strongly lined with the Pecking Order Theory; except for the fact that the relationship with tangibility has weakly confirmed the agency cost theory.

Few other researches have discussed other variables of this given subject; where, Pardesi (2011) have examined the applicapility of Pecking Order Theory of the capital structure on the textile firms, listed on the Karachi Stock Exchange, during the period 2004-2009. However, they have shown that, as compared to the traditional influence factors the Pecking Order Theory displays more persuading evidence about the banks' financing behavior.

On the other hand, Icke and Ivgen (2011) examined the firm-specific determinants of decision of capital structure in industrial firms listed in the Istanbul over he period 2004-2009 using the Panel Data Analysis. The results demonstrated undivided support for the Pecking Order Theory.

Jibran et al. (2012) have run a test on the validity of Pecking Order Theory for the decision of capital structure decsion in Pakistani's firms. A panel data analysis was employed to test the data of various firms. The value of t-test, R2, and F-Stat mentioned that the firms in KSE also support the weak shape of the theory.

Butt et al. (2013) stated that their study serves as a contribution towards comprehending the financial behavior of Pakistani's leasing firms over the period 2001-2010. Hence, it is concluded that the leasing sector adheres to the Pecking Order Theory.

Fumey and Isaack (2013) have examined whether the 'Pecking Order Theory' could explain dividend payout ratio using data of 33 firms on the Ghana Stock Exchange during the period 2004 to 2009. The findings reveal that there is a positive significant interaction between financial leverage and dividend payout ratio indicating that somewhat, the Pecking Order Theory explains dividend payout ratio in Ghana.

Hsu et al. (2013) investigated the well-known pecking order behaviors from the viewpoint of internationalization. This study's results show that the financing behaviors of the US firms are consistent with the Pecking Order Theory to some extent. In addition, the Pecking Order Theory applies more to multinational corporations (MNCs) than domestic corporations (DCs).

Chen et al. (2013) examined the market timing theory and the Pecking Order Theory from 1990-2005 using panel data of publicly-traded Taiwanese firms. The findings indicate no support for pecking order. Furthurmore, the results of market timing theory provide an explanation when the results are not consistent with the Pecking Order hypothesis.

Jahanzeb et al. (2014) examined the role of different capital structure theories in decision making regarding the debt preferences. Literature shows that the two theories i-e; Trade-Off and Pecking Order have always dominated the capital structure decisions but recent theoretical and empirical work shows that Market Timing Theory has also challenged the basic theories.

Matemilola et al. (2014) studied the association between cash flow and debt using panel generalized method of moment. Outcomes indicate that cash flow is negatively affects to both long term and total debt ratios. The results support the Pecking Order Theory of corporate financing and reveal that further development of the capital market is required to minimize the asymmetry of information.

Narmandakh (2014) analyzed the determinants of capital structure of 23 Mongolian listed firms, from the year 2010 to 2013. The results indicate that there is moderate support for modified Pecking Order Theory in Mongolian listed firms.

Baltac and Ayaydin (2014) explored the significance of macroeconomic, country, and firm specific factors in explaining capital structure using a sample of Turkish banks in the period 2002-2012. The study found that capital structure is significantly and positively related with firm size. Moreover, profitability, tangibilityand GDP growth are consistent with the predictions of the Pecking Order Theory, while firm size is in line with the predictions of the Trade-off Theory.

In Jordan, most studies on capital structure have been conducted using data from the industrial or service sectors where very few of them have used the financial sector, as it is with the study of Siam et al. (2005) which takes a 
close look into the capital structure of listed banking in Amman bourse (Amman Stock Exchange) in 2002 during the time period (1992-2001) by using firm-level panel data. However, it is shown that the size of the bank, retained earnings, liquidity, age and the long and short - term debts are determinants of leverage.

\section{Description of Variables and Hypothesis}

The factors have been proposed from the past studies related to, in general, determinants of capital ratio of firms, and of banks in particular, which includes:

\subsection{Dependent Variable (Capital Structure)}

The capital structure proxied by leverage is the dependent variable of this study. Wald (1999) makes a claim that as compared with the proportion of long-term debt, the ratio of total debt to total assets is more critical against financial crises. In line with this, in this study, the leverage is measured for by the book value of total liabilities to the book value of total assets. The reason to take the total liabilities is that it contains all of the deposits and non- deposit liabilities in the case of banks, which demonstrates the leverage in the best way possible. Book leverage has been interpreted as the ratio of book value of total debt to book value of total assets.

\subsection{Independent Variables}

\subsubsection{Growth}

Growth is related to an investment or project that has the possibility to grow significantly, leading to a profit that can be reaped by the investor. As the repercussion of the developments of banks, their necessity of finance will also increase. The potential to fund the increasing demand is very much reliant on internal finance. If a bank totally depends on internal fund, then the development might be restrained. Furthermore, the managers might have to neglect some lucrative projects. In case a bank leans more towards external finance, then the possibilities of risk will be raised. In this context, Myers (1977) has stated that, banks with the prospect of development will usually have a lesser amount of capital structure. Banks with higher growth will usually ascertain their external funds to accommodate the development that is to take place (Michaelas et al., 1999). Development probably contributes to the mounting pressure on the maintained income, and pushes the bank to borrow. Moreover, banks would anticipate more short-term and lesser long-term financing requirements.

The Pecking Order Theory indicates a positive effect of growth prospects on leverage, as banks are more comfortable utilising their internal financing, although these finances might not be enough. As the consequence, banks use debt financing, further indicating a positive relation of leverage with growth prospects (Drobetz \& Fix, 2003). Related works have identified that; growth has a positive association with capital structure (Bevan \& Danbolt, 2002; Eriotis, 2007).

Several authors have used a variety of intermediaries and proxies to ascertain growth opportunities. Guney et al. (2011) have adopted the growth rate of total assets as indicators of growth opportunities. In the current study, growth opportunity is calculated as the percentage change in total assets.

$\mathbf{H}_{1}$ : Growth will positively affect to capital structure of Jordanian banks.

\subsubsection{Dividends}

Dividends are defined as the portion of corporate profits paid out to stockholders (Sullivan \& Sheffrin, 2003). Bhaduri (2002) asserts that dividends are the indicator of financial wellness to outsiders. A bank that has a consistent flow of dividends might perhaps encounter lesser asymmetric information, when exposed to the equity market. Frank and Goyal (2004) have identified a direct association between dividend and leverage.

Justified by the Pecking Order Theory, there is a prediction of a positive association between the ratio of payout and capital structure. Payout ratio is interpreted as dividends all overprofit after tax or it can be used as dummy variable equal to one if the bank pays a dividend in a certain year (Gropp \& Heider, 2007).

$\mathbf{H}_{2}$ : Dividends will positively affect to capital structure of Jordanian banks.

\subsubsection{Tangibility}

Tangibility is an extensively acknowledged factor behind the capital structure. Fixed assets play the role as collateral, safeguarding the lenders against failures and losses triggered by the conflicts that break out between lenders and shareholders, or against losses incurred due to misinformation or the lack of it. Majority of the studies have affirmed that, the tangibility of assets determines the banks' financial leverage. The Pecking Order Theory further predicts that, banks that retain more tangible assets will be less susceptible to complications of asymmetric information, and they will be expected to minimize the agency cost. The agency costs of guaranteed debt, for example tangible assets are not more than those of unsecured debt. 
In this context, a few studies show there is a direct link between the portion of tangible assets and leverage consisting with the Pecking Order Theory (Michaelas et al., 1999; Amidu, 2007).

Bevan and Danbolt (2002); Cheng and Shiu (2007); Ramlall (2009); Céspedes et al. ( 2010); Yang et al. (2010); and Voutsinas and Werner (2011) have adopted the most ubiquitous means to measure tangibility as the ratio of fixed assets to total assets. In this study, the calculation works the same way.

$\mathbf{H}_{3}$ : Tangibility will positively affect to capital structure of Jordanian banks.

\subsubsection{Size}

Leaning on the Pecking Order Theory, bank size has a negative association with total debt for the reason that big companies tend to register high profits and thus will be willing to make investments based on their available internal funds.

The contradicting and conflicting overview of the negative relationship stems from information discrepancy and asymmetry issues. Rajan and Zingales (1995) further maintain that large banks are generally needed to reveal more information to the public, altogether increasing their visibility, mitigating their information asymmetry costs; and consequently resting more with equity financing. Mazur (2007); Shah (2007); and Chakraborty (2010) have demonstrated empirically a negative association between leverage and bank size.

Smaller banks with the problem of information asymmetry might not have the competency to increase the equity, due to equity overvaluation, and the lack of security for long-term debt, and such circumstances lead to short-term debt might be utilized by small banks, in which they are frequently governed by few managers, whose primary goal is to curb the invasion or intervention in their business; hence internal funds will be prominent as the their first choice of finance. In terms of insufficient internal funds, small banks will choose debt to new equity, primarily reasoned by the fact that debt indicates lesser degree of invasion and lower danger of losing control.

To add to this, Hussain and Matlay (2007) state that small banks tend to look for external sources of finance if their internal sources are draining. Conversely, small banks will try to fulfill their financial requirements with a pecking order of individual and retained incomes, alongside debt and issuance of new equity. The Pecking Order Theory might be easily and effortlessly applied in small banks, since they normally borrow for their investment needs, compared to an attempt to accomplish a capital structure that is considered optimal (Daskalakis \& Psillaki, 2008). As the consequence, the size of a bank has been regarded as moderator, which potentially interacts with the dependent variables and independent variables used in the empirical model.

Various studies have employed a variety of proxies, depending on the nature of business, to measure the size. Natural log of total sales has been used by many researchers as a proxy for variable size (Céspedes et al., 2010; Mishra \& Tannous, 2010).

Growth interacts with size: For smaller banks, proprietors also take the role as the bank managers. Proprietors prefer to be allowed to be authoritative of their banks, as they have the privilege to gain individual benefit over their investments' financial return. They have to cast aside some development possibilities, if the options are too important to be recognized and depend more on debt. The development of small banks is more susceptible to internal finance unlike the bigger banks (Cressy \& Olofsson, 1997). It is probable that small banks tend to have to deal with higher financial restrictions, which makes it harder for them to tap into the banking resources. The small banks are determined to pay higher interest rates for additional loans, and they do not stop to consider issuing external equity just to stay in control.

Dividends interact with size: As it is with the profitability factor, considering that large banks can find their way easier to obtain financial resources, it is fair to presume that, when releasing more dividends to their stock holders, the large banks might usually make the less borrowing, as opposed to the smaller banks (Padron et al., 2005).

Tangibility interacts with size: Smaller banks find it more challenging to be proffered financial services, as charges for information and transaction are higher (Cestone \& White, 2003). Information expense can be non-existent for internal finance, however, they are higher when new capital is issued, whilst, debt is placed in an intermediate. Fixed transaction costs facilitate the small banks by means of preventing them from obtaining financial services, and the costs support large banks disproportionately. Small banks are not prone to endure higher operational risks and higher financial distress risk. In a lot of occasions, banks react to these risks based on the value of the collateral available. This poses a challenge for small banks, where, they do not generally have substantial fixed assets as security (Tucker \& Lean, 2003). The commonly existing asymmetric information in small banks might also persuade lenders to seek out guarantees in collateral (Myers, 1977; Harris \& Raviv, 
1990).

$\mathbf{H}_{4}$ : Bank's size will moderate the relationship between independent variables and capital structure of Jordanian banks.

\section{Data and Methodology}

\subsection{Data Collection}

The database of the Amman Stock Exchange and data of banks have served as the basis for the analysis. The Jordanian Central Bank report in 2013 explained that financial sector accounts for almost $60 \%$ of the entire stock market value and the banking system constitutes roughly $94 \%$ of the financial sector sizer. The study population comprised of all local/national banks that have an active operation in Jordan, and these banks totaled (16) banks. Based on the availability of the financial data, the sample comprises a total of 14 Jordanian banks (or with regard to type, 13 commercial and 1 Islamic banks), where the data set covers the years of 1999 to 2013.

\subsection{Method of Analysis}

The paper has been guided by descriptive and econometric analyses. The descriptive approach serves to analyze the means. A preliminary estimation of the correlation coefficients of the variables was carried out to determine the explanatory variables that would finally establish themselves in the regression model. The econometric approach will study the main factors that have an effect on the banks' capital structure in Jordan.

Using the panel data structure, the estimation of the OLS regression has been implemented using both the Random Effects (RE) and Fixed Effects (FE). The results of the fixed effects would be drawn in comparison to that obtained from the random effects via the Hausman (1978) specification test. Afterwards, the chosen model is tested for following of the OLS approach's assumption. The test of heteroscedasticity, follows the test of Breusch-Pagan LM test of independence to test if there is heteroscedasticity present. Hence, the model cannot be used for inferences. In the next step, a test is carried out to see if the data/model estimated has been adhering to any autocorrelated structure.

The Wooldridge test is adopted for autocorrelation in panel data to see the presence of autocorrelation, and as a result, an approach that can control these issues in panel data is applied. To do this, the FGLS based approach needs to be applied. Three explanatory variables are included in the regression analysis. Firstly, the capital structure is regressed on the three explanatory variables to check on their respective significance. Then the moderator variable (SIZE) and its interaction with all the explanatory variables are included into the regression model in order to see the moderating effects present.

Based on the literature review on capital structure along with the theories of capital structure; this present study constructs the following models:

Fixed Effect Model:

$$
L E V_{i t}=\beta_{0 i}+\beta_{1}\left(G O_{i t}\right)+\beta_{2}\left(D V_{i t}\right)+\beta_{3}\left(T A N G_{i t}\right)+\mu_{i t}
$$

Random Effect Model:

$$
L E V_{i t}=\beta_{0}+\beta_{I}\left(G O_{i t}\right)+\beta_{2}\left(D V_{i t}\right)+\beta_{3}\left(T A N G_{i t}\right)+\mu_{t}+\varepsilon_{i}
$$

$\mathrm{LEV}_{i t}=$ leverage of the bank $i$ at time $t$;

$\mathrm{GO}_{i t}=$ Growth of bank $i$ at time $t$;

$\mathrm{DV}_{i t}=$ Dividends of bank $i$ at time $t$;

$\mathrm{TANG}_{i t}=$ Tangibility of assets of the bank $i$ at time $t$;

$\mu_{i t}=$ error of the bank $i$ in time $t$;

$\mu_{t}=$ error in time $t$;

$\varepsilon_{i}=$ error of bank $i$.

The Feasible Generalized Least Squares (FGLS) covers the case where you do not have the knowledge of this covariance matrix, but estimation is possible. The random effects model uses FGLS assume that

$$
\begin{gathered}
Y_{i t}=X_{i t} \beta+\theta_{i}+\varepsilon_{i t} \\
E\left[\theta_{i}\right]=E\left[\varepsilon_{i t}\right]
\end{gathered}
$$

To test moderation effect, the following equation to determine the significance of $\mathrm{x}^{*} \mathrm{~s}$ is used:

$$
Y=a+b X+g s+u X^{*}+e
$$


Where : $a, b, g$ and $u$ are coefficients of regression;

$\mathrm{e}$ is error term;

$\mathrm{x}$ is independent variables;

$\mathrm{s}$ is moderator;

$\mathrm{x}^{*} \mathrm{~s}$ is interaction term.

\section{Results Analysis}

\subsection{Results of the Descriptive Statistics}

In table 1, the analysis of the means highlights the following descriptive statistics: capital structure (leverage) (M $=0.884, \mathrm{SD}=0.072)$; growth $(\mathrm{M}=7.128, \mathrm{SD}=25.183)$; dividends $(\mathrm{M}=0.585, \mathrm{SD}=0.494)$; tangibility $(\mathrm{M}=$ $0.021, \mathrm{SD}=0.017)$. The analysis suggests that the growth has the highest mean $(\mathrm{M}=7.128)$, with the deviation from the mean showing at 25.183 . The standard deviation for leverage $(0.072)$ indicates that the data are clustered around the mean and therefore, this is seemingly reliable.

Table 1. Descriptive statistics for the variables

\begin{tabular}{llllllllll}
\hline Variable & Mean & Std. Dev. & Minimum & Maximum & P10 & P25 & P50 & P75 & P90 \\
\hline Leverage & .883747 & .072421 & .310744 & 1.31354 & .824668 & .848039 & .882899 & .911653 & .93969 \\
Growth & 7.127865 & 25.1827 & -99.02386 & 88.51699 & -3.95012 & 3.68767 & 9.28110 & 15.9732 & 25.2154 \\
Dividends & .5848214 & .4938564 & 0 & 1 & 0 & 0 & 1 & 1 & 1 \\
Tangibility & .0214898 & .0166334 & .0027183 & .1008617 & .0081983 & .011441 & .0170049 & .025017 & .040942 \\
\hline
\end{tabular}

\subsection{Discussions of Econometric Results}

Table 2 below presents the results of the correlation analysis for the study in order to determine the level of association among the variables. Correlation explains change in one variable because of the change in other variable. If a significant correlation is found between predictors, it can cause the multicollinearity, which can manipulate results. So predictors of a good model should be free from this correlation. 0.6 is a cut point of correlation and beyond this point multicollinearity exists (categorization of Dancey \& Reidy, 2004). If correlation is exactly 1 , it means variables are perfectly multicollinear. However, if there is a correlation above the cut point but this relation is insignificant, it means that variables are free from multicollinearity.

Bank growth has non significant direct correlation with dividends and significant inverse relationship with tangibilty of banks, but correlation values are below from cut point 0.6 . Similarly, dividends of the banks and their tangibility have significant inverse correlation below the point 0.6 .

Table 2. The correlation of variables

\begin{tabular}{lllll}
\hline Variable & Leverage & Growth & Dividends & Tangibility \\
\hline Leverage & 1.0000 & & & \\
Growth & -0.2235 & 1.0000 & & \\
& 0.0008 & & & \\
Dividends & -0.1733 & 0.0349 & 1.0000 & \\
& 0.0094 & 0.6040 & & \\
Tangibility & 0.3045 & -0.4518 & -0.2504 & 1.0000 \\
& 0.0000 & 0.0000 & 0.0002 & \\
\hline
\end{tabular}

It is clear from the above discussion that all the predictors of model are free from multicollinearity and the level of significance among predictors is not up to the mark which will cause multicollinearity and manipulate results of estimated model. Even though variables have significant correlation with each other, but value is below the cut point 0.6 . Hence, it is proved that all explanatory variables are not correlated up to that extent which causes multicollinearity.

Two panel data regression techniques i.e. fixed effect and random effect, are employed for this study. The results of the correlated random effects - Hausman test (not given here), performed to decide between fixed or random effects, shown that the random effects model is more appropriate than the fixed effects model $\left(\mathrm{Chi}^{2}=0.1166\right.$ 
(P-value exceeding 0.05, $\left.\mathrm{Chi}^{2}=5.90\right)$ ).

Then, the random effect model is tested for following the assumption of the OLS approach. The test of heteroscedasticity, after the test of Breusch-Pagan LM test of independence $\left(\mathrm{Chi}^{2}(10)=12.107\right.$, P-value $=$ 0.2780) confirmed the presence of heteroscedasticity. Hence, the random effect model cannot be employed for inferences. Next, it is needed to test if the data/model estimated had been following any auto-correlated structure. Using the test of the Wooldridge test for autocorrelation in panel data indicates the presence of autocorrelation ( $\mathrm{F}$ $(1,4)=94.743$, P-value $=0.0006)$. In effect, to control these issues in panel data, FGLS-based approach was used.

Table 3. The regression results based on the FGLS model

First model

\begin{tabular}{lcccccc}
\hline \multicolumn{2}{l}{$\begin{array}{l}\text { Dependent variable: Capital Structure (Lev) } \\
\text { Variable }\end{array}$} & Coefficient & Std. Error & $\mathbf{Z}$ & $\mathbf{P}>|\mathbf{z}|$ & \multicolumn{1}{c}{ [95\% Conf. Interval] } \\
\hline Growth & .0000492 & .000071 & 0.69 & 0.488 & -.0000899 & .0001884 \\
Dividends & -.0077334 & .003522 & -2.20 & 0.028 & -.0146364 & -.0008305 \\
Tangibility & .436968 & .1583327 & 2.76 & 0.006 & .1266416 & .7472944 \\
Constant & .8712982 & .0065705 & 132.61 & 0.000 & .8584203 & .8841761 \\
\hline
\end{tabular}

Second model

\begin{tabular}{lllllll}
\hline $\begin{array}{l}\text { Dependent Variable: } \\
\text { Variable }\end{array}$ & Coefficient & Std. Error & $\mathbf{Z}$ & $\mathbf{P}>|\mathbf{z}|$ & \multicolumn{1}{l}{ [95\% Conf. Interval] } \\
\hline Growth & .0004072 & .0018403 & 0.22 & 0.825 & -.0031998 & .0040142 \\
Dividends & .1495862 & .11773 & 1.27 & 0.204 & -.0811603 & .3803327 \\
Tangibility & -3.153539 & 3.550499 & -0.89 & 0.374 & -10.11239 & 3.80531 \\
Size & -.0083678 & .016023 & -0.52 & 0.602 & -.0397722 & .0230366 \\
Size_Growth & -.0000431 & .0002131 & -0.20 & 0.840 & -.0004609 & .0003746 \\
Size_Dividends & -.0178579 & .013313 & -1.34 & 0.180 & -.0439509 & .0082351 \\
Size_Tangibility & .396077 & .4027085 & 0.98 & 0.325 & -.3932172 & 1.185371 \\
Constant & .9530826 & .14158 & 6.73 & 0.000 & .6755909 & 1.230574 \\
\hline
\end{tabular}

Note. Significant at 5\% level and Significant at $10 \%$ level.

From the regression output listed in Table 3, the coefficients of the regressors suggest how much capital structure changes when there is a change observed in the growth, dividends and tangibility. From Table 3, the overall regression is statistically significant, Wald $\mathrm{Chi}^{2}(3)=21.01, \mathrm{Prob}>\mathrm{Chi}^{2}=0.0038$, thus shedding light on the fact that growth, dividends and tangibility are important factors in determining the capital structure of the Jordanian banks.

The interpretation of the result can be performed through the models. In the first model, main effects of the explanatory variables are investigated. Significant positive relation between capital structure and tangibility, the regression coefficient of tangibility is harmonious with the Pecking Order Theory. A significant and negative association is also noted between capital structure and dividends. The variable dividend is not predicted by this theory. However, a positive relation between capital structure and growth is observed, but its compliance with the Pecking Order Theory is not significant.

The most significant variable is tangibility, where the coefficient of tangibility is positive. This suggests that higher proportion of fixed assets in total assets will reduce the asymmetric information problems and more debts should be underway. This supports the Pecking Order Theory and altogether, confirms the findings of some previous studies Gaud et al. (2005); Gropp and Heider (2010); Kiran (2013).

The coefficient of growth and capital structure is not significantly positive. Banks with high growth are prone to exhaust internal funds and thus additional capital is required (Michaelas et al., 1999). Growth has the tendency to put a strain on retained earnings and the bank will then be propelled to borrow.

The dividend in this study has a relationship with capital structure but is not consistent with the Pecking Order Theory. The banks with good financial health may be accountable for most of their profitability to maintain the level of the previous dividend policy. 
Size is integral to the capital structure. The most foreground question is that, could the size factor justify or explain any differences on capital structure. The size serves to be a moderator variable in this study. The real effect of the moderator was not observed in any of the independent factors. There was a modification on the direction and strength of the relation between them and capital structure but it was not significant.

\section{Conclusions}

This study establishes an analysis of the determinants of capital structure choices of Jordan banks based on the data taken from 14 listed banks from the years of 1999-2013. The study offers contribution on the empirical literature on capital structure in two ways. In the first way, it belongs to the scarcity of studies which probe into the capital structure of the emerging stock market. In the second, it makes a comparison of the influence of bank size to the determinants. Conclusively, the empirical evidence from this study proposes that growth, dividends and tangibility are important variables that determine the bank's capital structure. Growth positively affects capital structure but the effect was not significant. Applying the Pecking Order Theory, growing banks impose a greater demand on financial funds. They will turn their attention to external funds to finance the growth.

The dividend policy has a relation with capital structure within the period of 1999-2013. The result was not in the same direction of the Pecking Order Theory, perhaps the financial crisis is the moderator of the results. The assets structure (tangibility) is associated with the capital structure demonstrating an additional evidence to support and achieve the Pecking Order Theory.

Size of bank is the path moderator between the examined variables growth, dividends and tangibility with capital structure. There was an observed change in the direction and strength of the relation between them and leverage, but the modification on that relation was not significant.

This study proposes that the key players in banking sector such as policy makers, financial analysts and managers of banks are encouraged to use the outcomes to have a better understanding about the factors that may affect the banks capital structure which at the end will enhance and promote the competition in the sector.

\section{References}

Abu Jalal, M. (2007). The Pecking Order, Information Asymmetry, and Financial Market Efficiency. USA: University of Minnesota.

Ahmad, R., Ariff, M., \& Skully, M. (2009). Determinants of Bank Capital Ratios in a Developing Economy. Working Paper, University of Tokyo.

Amidu, M. (2007). Determinants of capital structure of banks in Ghana: An empirical approach. Baltic Journal of Management, 2(1), 67-79. http://dx.doi.org/10.1108/17465260710720255

Atiyet, B. A. (2012). The Pecking Order Theory and the Static Trade Off Theory: Comparison of the Alternative Explanatory Powerin French. Journal of Business Studies Quarterly, 4(1), 1-14.

Baltac, N., \& Ayaydın, H. (2014). Firm, Country and Macroeconomic Determinants of Capital Structure: Evidence from Turkish Banking Sector. Emerging Market Journal, 3(3). http://dx.doi.org/10.5195/emaj.2014.46

Bessler, W., Drobetz, W., \& Gruninger, M. C. (2010). International Tests of the Pecking Order Theory. Working Paper, Midwest Finance Association (MFA), 1-47.

Bevan, A. A., \& Danbolt, J. (2002). Capital structure and its determinants in the United Kingdom - A de-compositional analysis. Applied Financial Economics, 12(3), 159-170. http://dx.doi.org/10.1080/09603100110090073

Bhaduri, S. (2002). Determinants of corporate borrowing: Some evidence from the Indian corporate structure. Journal of Economic and Finance, 26, 200-215. http://dx.doi.org/10.1007/BF02755986

Butt, S., Khan, Z. A., \& Nafees, B. (2013). Static Trade-off theory or Pecking Order Theory which one suits best to the financial sector. Evidence from Pakistan. European Journal of Business and Management, 5(23).

Caglayan, E., \& Sak, N. (2010). The determinants of capital structure: Evidence from the Turkish banks. Journal of Money, Investment and Banking, 15, 57-65.

Céspedes, J., González, M., \& Molina, C. A. (2010). Ownership and capital structure in Latin America. Journal of Business Research, 63(3), 248-254. http://dx.doi.org/10.1016/j.jbusres.2009.03.010

Cestone, G., \& Lucy, W. (2003). Anti-Competitive Financial Contracting: The Design of Financial Claims. Journal of Finance, 58, 2109-2142. http://dx.doi.org/10.1111/1540-6261.00599 
Chakraborty, I. (2010). Capital structure in an emerging stock market: The case of India. Research in International Business and Finance, 24, 295-314. http://dx.doi.org/10.1016/j.ribaf.2010.02.001

Chen, D. H., Chen, C. D., Chen, J., \& Huang, Y. F. (2013). Panel data analyses of the Pecking Order Theory and the market timing theory of capital structure in Taiwan. International Review of Economics and Finance, 27(C), 1-13.

Cheng, S. R., \& Shiu, C. Y. (2007). Investor protection and capital structure: International evidence. Journal of Multinational Financial Management, 17(1), 30-44. http://dx.doi.org/10.1016/j.mulfin.2006.03.002

Cressy, R., \& Olofsson, C. (1997). European SME Financing: An Overview. Special Issue of Small Business Economics. Small Business Economics, 9, 87-96. http://dx.doi.org/10.1023/A:1007921004599

Dancey, C., \& Reidy, J. (2004). Statistics without Maths for Psychology: Using SPSS for Windows. London: Prentice Hall.

Dang, V. A. (2013). Testing Capital Structure Theories Using Error Correction Models: Evidence from the UK, France and Germany. Applied http://dx.doi.org/10.1080/00036846.2011.597724

Daskalakis, N., \& Psillaki, M. (2008). Do country of firm factors explain capital structure? Evidence from SMEs in France and Greece. Applied Financial Economics, 18, 87-97. http://dx.doi.org/10.1080/09603100601018864

De Jong, A., Verbeek, M. J. C. M., \& Verwijmeren, P. (2011). Firms' debt-equity decisions when the static tradeoff theory and the Pecking Order Theory disagree. Journal of Banking and Finance, 35(5), 1303-1314. http://dx.doi.org/10.1016/j.jbankfin.2010.10.006

Drobetz, W., \& Fix, R. (2003). What are the Determinants of the Capital Structure? Some Evidence for Switzerland. University of Basel. WWZ/Department of Finance, Working Paper (4/03).

Eriotis, N. (2007). How firm characteristics affect capital structure: An empirical study. Managerial Finance, 33(5), 321-331. http://dx.doi.org/10.1108/03074350710739605

Frank, M. Z., \& Goyal, V. K. (2004). Capital structure decisions: Which factors are reliably important? EFA 2004 Maastricht Meetings Paper No. 2464, Tuck Contemporary Corporate Finance Issues III Conference paper.

Fumey, A., \& Isaack, D. (2013). Dividend Payout Ratio in Ghana: Does the Pecking Order Theory Hold Good. Journal of Emerging Issues in Economics, Finance and Banking, 2(5), 99-133.

Gaud, O., Jani, E., Hoesli, M., \& Bender, A. (2005). The capital structure of Swiss firms: An empirical analysis using dynamic panel data. European Financial Management, 11, 51-69. http://dx.doi.org/10.1111/j.1354-7798.2005.00275.x

Gropp, R., \& Heider, F. (2007). What Can Corporate Finance Say About Banks' Capital Structures. European Central Bank working paper.

Gropp, R., \& Heider, F. (2010). The determinants of bank capital structure. Review of Finance, 14(4), 587-622. http://dx.doi.org/10.1093/rof/rfp030

Guney, Y., Li, L., \& Fairchild, R. (2011). The relationship between product market competition and capital structure in Chinese listed banks. International Review of Financial Analysis, 20(1), 41-51. http://dx.doi.org/10.1016/j.irfa.2010.10.003

Harris, M., \& Raviv, A. (1990). Capital structure and the informational role of debt. Journal of Finance, 45(2), 321-349. http://dx.doi.org/10.1111/j.1540-6261.1990.tb03693.x

Harris, M., \& Raviv, A. (1991). The theory of capital structure. Journal of Financial Economics, 41, 297-355.

Hsu, C. H., Chiang, Y. C., \& Liao, T. L. (2013). Testing pecking order behaviors from the viewpoint of multinational and domestic corporations. Investment Management and Financial Innovations, 10(2).

Hussain, J., \& Matlay, H. (2007). Financing preferences of ethnic minority owner/managers in the UK. Journal of Small Business and Enterprise Development, 14(3), 487-500. http://dx.doi.org/10.1108/14626000710773565

Icke, B. T., \& Ivgen, H. (2011). How bank specific factors affect capital structure: an emerging market practiceIstanbul stock exchange (ISE). Middle Eastern Finance and Economics, 13, 90-102. 
Jahanzeb, A., Saif-Ur-Rehman, B. N. H., Karami, M., \& Ahmadimousaabad, A. (2014). Trade-Off Theory, Pecking Order Theory and Market Timing Theory: A Comprehensive Review of Capital Structure Theories. International Journal of Management and Commerce Innovations (IJMCI), 1(1), 11-18.

Jibran, S., Wajid, S., Waheed, I., \& Muhammad, T. (2012). Pecking at Pecking Order Theory: Evidencefrom Pakistan's Non-financial Sector. Journal of Competitiveness, 4(4), 86-95. http://dx.doi.org/10.7441/joc.2012.04.06

Jindrichovska, I., Ugurlu, E., \& Kubickova, D. (2013). Changes in Capital Structure of Czech SMEs: A Dynamic Panel Data Approach. The International Istanbul Finance Congress-2013, Kadir Has University, Cibali Campus, Istanbul, Turkey.

Karadeniz, E., Kandir, Y. S., Balcilar, M., \& Onal, B. Y. (2009). Determinants of capital structure: Evidence from Turkish lodging companies. International Journal of Contemporary Hospitality Management, 21(5), 594-609. http://dx.doi.org/10.1108/09596110910967827

Kiran, S. (2013). Determinants of capital structure: a comparative analysis of textile, chemical and fuel and energy sectors of Pakistan (2001-2006). International Review of Management and Business Research, 2(1), $37-47$.

Leary, M. T., \& Roberts, M. R. (2010). The pecking order, debt capacity, and information asymmetry. Journal of Financial Economics, 95(3), 332-355. http://dx.doi.org/10.1016/j.jfineco.2009.10.009

Marc. (2010). Rating Approach to Construction Companies. Policy Reference, 1-11.

Matemilola, B. T., Bany-Ariffin, A. N., \& Annuar, M. N. (2014). Debt and Cash flow Relationship in Pecking Order Theory of Corporate Financing: Dynamic Panel Evidence. The Empirical Economics Letters, 13(6), 1681-8997.

Mazur, K. (2007). The determinants of capital structure choice: Evidence from Polish Companies. International Atlantic Economic Society, 13, 495-514.

Michaelas, N., Chittenden, F., \& Poutziousris, P. (1999). Financial policy and capital structure choice in UK SMEs: Empirical evidence from company panel data. Small Business Economics, 12, 113-130. http://dx.doi.org/10.1023/A:1008010724051

Mishra, D., \& Tannous, G. (2010). Securities laws in the host countries and the capital structure of US multinationals. International Review of Economics \& Finance, 19(3), 483-500. http://dx.doi.org/10.1016/j.iref.2009.10.013

Modigliani, F., \& Miller, M. H. (1958). The cost of capital, corporation finance and the theory of investment. American economic Review, 48(3), 261-297.

Myers, S. C. (1977). Determinants of capital borrowing. Journal of Finance Economics, 5, 5147-5175. http://dx.doi.org/10.1016/0304-405X(77)90015-0

Myers, S. C. (1984). Capital structure puzzle: National Bureau of Economic Research Cambridge. Mass., USA. http://dx.doi.org/10.3386/w1393

Myers, S. C., \& Majluf, N. (1984). Corporate financing and investment decisions when firms have information that investors do not have. Journal of Financial Economics, 13, 187-221. http://dx.doi.org/10.1016/0304-405X(84)90023-0

Narmandakh, B. (2014). Determinants of Capital structure: Pecking Order Theory. Evidence from Mongolian listed firms. 3rd IBA Bachelor Thesis Conference, Enschede, University of Twente, The Netherlands.

Oolderink, P. (2013). Determinants of capital structure: Static trade-off theory vs. Pecking-order theory Evidence from Dutch listed firms. University of Twente, The Netherlands.

Padron, Y. G., Apolinario, R. M. C., Santana, O. M., Marlel, V. C. M., \& Sales, L. J. (2005). Determinant factors of leverage: An empirical analysis of Spanish corporations. Journal of Risk Management, 6, 60-68.

Pardesi, A. (2011). Pecking Order Theory: An Empirical Test of Textile Firms Listed on the Karachi Stock Exchange. http://dx.doi.org/10.2139/ssrn.1907512

Rajan, R. G., \& Zingales, L. (1995). What do we know about capital structure? Some evidence from international data. The Journal of Finance, 50(5), 1421-1460. http://dx.doi.org/10.1111/j.1540-6261.1995.tb05184.x

Ramlall, I. (2009). Determinants of capital structure among non-quoted Mauritian banks under specificity of 
leverage: looking for a modified Pecking Order Theory. International Research Journal of Finance and Economics, 1 .

Roerink, S. H. S. (2014). Testing the static trade-off theory and the Pecking Order Theory of capital structure: Evidence from Dutch listed firms. University of Twente, The Netherlands.

Serrasqueiro, Z., Rogão, M., \& Nunes, P. M. (2014). Capital Structure Decisions of European and U.S. Listed Firms: Is there a Unique Financial Theory. Research and Applications in Economics, 2.

Shah, S. (2007). Corporate debt policy- pre-and post-financial market reforms: The case of the textile industry of Pakistan. The Pakistan Development Review, 46(4), 465-478.

Siam, W. Z., Khrawish, H. A., \& El-Hammoury, B. M. (2005). The Capital Structure of Banking Sector in Jordan. Dirasat, Administrative Sciences, 32(1).

Simiyu, L. A., \& Huo, X. (2013). Factors Affecting Leveraging for Quoted Real Estate Development Companies in China. International Journal of Economics and Finance, 5(7). http://dx.doi.org/10.5539/ijef.v5n7p85

Sullivan, A., \& Sheffrin, S. (2003). Economics: Principles in Action. New Jersey: Upper Saddle River.

Tucker, J., \& Lean, J. (2003). Small firm finance and public policy. Journal of Small Business and Enterprise Development, 10(1), 50-61. http://dx.doi.org/10.1108/14626000310461367

Voutsinas, K., \& Werner, R. A. (2011). Credit supply and corporate capital structure: evidence from Japan. International Review of Financial Analysis, 320-334. http://dx.doi.org/10.1016/j.irfa.2011.05.002

Wald, J. K. (1999). How bank characteristics affect capital structure: An international comparison. Journal of Financial Research, 22(2), 161-187. http://dx.doi.org/10.1111/j.1475-6803.1999.tb00721.x

Yang, C. C., Lee, C., Gu, Y. X., \& Lee, Y. W. (2010). Co-determination of capital structure and stock returns-A LISREL approach: An empirical test of Taiwan stock markets. The Quarterly Review of Economics and Finance, 50(2), 222-233. http://dx.doi.org/10.1016/j.qref.2009.12.001

\section{Copyrights}

Copyright for this article is retained by the author(s), with first publication rights granted to the journal.

This is an open-access article distributed under the terms and conditions of the Creative Commons Attribution license (http://creativecommons.org/licenses/by/3.0/). 